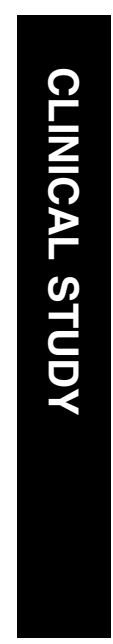

\title{
Amniotic membrane transplantation for persistent corneal epithelial defects in eyes after penetrating keratoplasty
}

${ }^{1}$ Department of Ophthalmology, University of Saarlandes, Homburg/ Saar, Germany

${ }^{2}$ L V Prasad Eye Institute, Bhubaneswar, Orissa, India

${ }^{3}$ Department of Ophthalmology, University of Erlangen-Nürnberg, Erlangen, Germany

Correspondence: B Seitz, Direktor der Klinik für Augenheilkunde, Universitätsklinikum des Saarlandes UKS, Kirrberger Straße, Homburg/Saar D-66421, Germany

Tel: + 4968411622387

Fax: + 4968411622400

E-mail: berthold.seitz@

uks.eu

Received: 3 December 2007 Accepted in revised form: 15 April 2008 Published online: 6 June 2008

\begin{abstract}
Purpose To determine the primary success and recurrence rate of amniotic membrane transplantation (AMT) for the treatment of persistent corneal epithelial defects (PEDs) in eyes after penetrating keratoplasty (PK). Design Retrospective, non-randomized, observational case series.
\end{abstract}

Method AMT was performed in 24 eyes of 24 patients with erosions $(n=6)$ or ulcers $(n=18)$, which were resistant to medical therapy. All eyes had undergone one $(42 \%)$ or more PKs before AMT. After the removal of epithelium and pannus (if present), one or more layers of AM ('graft' $(n=3)$, 'patch' $(n=5)$, 'sandwich' = combination of graft/patch $(n=16))$ were transplanted. Main outcome measures included 'surgical success' (epithelium closed within 4 weeks after AMT), and 'recurrence' (new epithelial defect developing during follow-up after surgical success).

Results The rate of surgical success was $70 \%$ and was found to be inversely proportional to the number of previous PKs. Defects limited only to the centre of the graft had a higher success rate (central: $100 \%$, non-central: $61 \%$ ). A total of $44 \%$ successful eyes (erosions: $75 \%$ vs ulcers: $33 \%$ ) had a recurrence after a mean follow-up of $16 \pm 13$ months. The rate of surgical success was highest (81 vs 67 vs 25\%) and the rate of recurrence was lowest (38 vs 90 vs $100 \%$ ) with the sandwich technique in contrast to the graft or patch techniques used alone.

Conclusions AMT may be beneficial in the treatment of PEDs after PK, especially when applying the sandwich technique. Recurrences
B Seitz 1 , S Das², R Sauer ${ }^{3}$, D Mena ${ }^{3}$ and C Hofmann-Rummelt ${ }^{3}$ seem to be more frequent, if PK preceded AMT.

Eye (2009) 23, 840-848; doi:10.1038/eye.2008.140; published online 6 June 2008

Keywords: amniotic membrane transplantation; persistent epithelial defect; corneal ulcer; penetrating keratoplasty

Introduction

Persistent corneal epithelial defects (PEDs) are defined as full thickness loss of epithelial cells that fail to show healing during a given time course. ${ }^{1}$ PEDs are induced by primary ocular surface disorders, such as chemical injury, neurotrophic keratitis, and keratoconjunctivitis sicca, or associated with systemic diseases, such as Fuchs-Stevens-Johnson syndrome and ocular cicatricial pemphigoid. The term 'erosion' indicates that the stroma is not involved, whereas in the case of an 'ulcer' the stroma is also damaged. These disorders cause prolonged inflammation of the ocular surface, which might alter limbal stem cells (LSCs) and the epithelial basement membrane (BM). ${ }^{2}$

Overall, late epithelial defects appear in $4.2 \%$ of eyes after penetrating keratoplasty (PK). ${ }^{3}$

They are more common in the context of limbal stem cell deficiency. PED is one of the major complications of PK and increases the risk of infection and degradation of stromal collagen. ${ }^{4}$ It not only reduces visual acuity but may also lead to corneal scarring, neovascularization, thinning, and progressive stromal ulceration thereby threatening the survival of the graft and even the eye. ${ }^{5}$ 
Amniotic membrane (AM) represents a thick BM, which facilitates migration of epithelial cells, reinforces adhesion of basal epithelial cells, ${ }^{6,7}$ promotes cellular differentiation, ${ }^{8-11}$ and prevents cellular apoptosis. ${ }^{12,13}$ However, the latter is not true for inflammatory cells. It is supposed to have anti-inflammatory and antiangiogenic properties. ${ }^{14}$ Another proposed mechanism through which AM facilitates epithelialization might be its function as a bandage contact lens protecting the migrating epithelial cells from the shearing movements of the eyelids. ${ }^{15,16} \mathrm{AM}$ is also effective in preventing excessive fibrosis during ocular surface reconstruction. ${ }^{17}$ It acts as a physical barrier, protecting the corneal stroma from damaging inflammatory cells and proteins in the tear film. In addition, AM may act through soluble factors that are influencing inflammatory cells that migrate from the limbal vasculature into the cornea.

AM can be used in patients with PEDs after previous PK to preserve the existing graft and to eliminate the need for more invasive procedures, such as regraft, which in turn increases the risk of immunological graft rejection.

The purpose of this retrospective clinical study was to determine the success rate of AMT for the treatment of PEDs in eyes after one or more previous PKs, and to evaluate the rate of recurrences after primary success.

\section{Patients and methods}

\section{Patients}

Between July 1999 and December 2004, 350 eyes underwent AM transplantation (AMT) in the Department of Ophthalmology, University of ErlangenNürnberg, Erlangen, Germany. Out of these, 24 eyes of 24 patients (15 male patients and nine female patients with a mean age of $60 \pm 20$ years, 12 left eyes and 12 right eyes) met the inclusion criteria for this retrospective clinical study: (i) one or more previous PKs, (ii) PEDs resistant to medical therapy, and (iii) first AMT. Six eyes had corneal erosions without stromal defect and eighteen eyes had ulcers. Mean age of the patients with erosions was $56 \pm 22$ years (three male patients and three female patients) and with ulcers was $62 \pm 19$ years (12 male patients and six female patients). Before AMT, medical treatment was performed for 9-32 days. Various non-surgical modes of management were tried such as lubricating drops, autologous serum, and eye-patching and bandage contact lens before planning for AMT.

Clinical data considered for the study were demography, number and history of PK, laterality, aetiology, localization, size and depth of the lesion, intraocular pressure, degree of vascularization, visual acuity, and slit-lamp examination at 1, 3, 6, and 12 months and yearly afterwards, if available (see Table 1). Mean follow-up was $15 \pm 12$ (range: $1-39$ ) months (18 \pm 18 and $15 \pm 10$ months for erosions and ulcers, respectively).

The patients were divided into three groups depending on the number of previous PKs before AMT: (i) with one previous PK $(n=11,46 \%)$; (ii) with two previous PKs $(n=8,33 \%)$, and (iii) with three or more previous PKs $(n=5,21 \%)$. Patients with erosions had one previous $\mathrm{PK}$ in one eye (17\%), two previous PKs in four eyes $(66 \%)$, and three or more previous PKs in one eye $(17 \%)$. Similarly, patients with ulcers had one previous PK in 10 eyes (56\%), two previous PKs in four eyes (22\%), and three or more previous PKs in four eyes (22\%).

Size of the lesions was measured using the Haag-Streit slit lamp. Erosions had a mean length of $4.2 \pm 1.9 \mathrm{~mm}$ and width of $3.3 \pm 2.3 \mathrm{~mm}$. Ulcers had a mean length of $3.5 \pm 2.2 \mathrm{~mm}$, a width of $3.0 \pm 1.7 \mathrm{~mm}$, and a depth ranging between 20 and $80 \%$ of stromal thickness. In 19 eyes $(80 \%)$, the defect was restricted to the graft $(100 \%$ of erosions, $72 \%$ of ulcers), whereas in five eyes $(20 \%)$ the defect involved both, the periphery of the graft and the host rim including the graft-host junction (Table 2). Stromal vascularization was noted in 16 eyes (67\%; five out of six with erosions and 11 out of 18 with ulcers) before surgery.

\section{Interventions}

The human AM was prepared and preserved in our own laboratory using a method previously described by Lee and Tseng. ${ }^{18}$ AMT was performed in $17 \%$ of eyes under general, $75 \%$ of eyes under retrobulbar, and $8 \%$ of eyes under topical anaesthesia. After the removal of epithelium and pannus (if present), one or more layers of AM depending on the depth of the lesion were fixed with multiple interrupted 10-0 nylon sutures. AM was applied by three different surgical techniques, which include: (i) 'inlay' ('graft') technique where the AM was sized slightly smaller than the size of the defect and sutured into place with the epithelial BM side facing up (Figure 1a). The AM functions as a BM over which a new corneal epithelium can grow, (ii) the 'overlay' ('patch') technique in which AM was placed over the entire cornea, limbus and perilimbal area (Figure 1b), and (iii) the 'sandwich' technique (Figure 1c), which was a combination of patch and one or more graft. ${ }^{19}$ In general, a pure single or multilayer graft was used in case of localized deep stromal defects with intact cornea around the lesion. A patch was used in case of pure epithelial defects or shallow stromal defects with good visual prognosis, since the patch is not integrated into the host cornea. A sandwich was used in case of deep stromal 
Table 1 Demographic data of patients with persistent epithelial defect treated with amniotic membrane transplantation

\begin{tabular}{|c|c|c|c|c|c|c|c|c|c|c|c|c|c|c|}
\hline \multirow{3}{*}{$\begin{array}{l}\text { Age (years) } \\
\text { sex (male) } \\
\text { female) } \\
1\end{array}$} & \multirow{3}{*}{$\begin{array}{c}\text { Number } \\
\text { of PK before } \\
\text { AMT } \\
\\
2\end{array}$} & \multirow{3}{*}{$\begin{array}{l}\text { Primary } \\
\text { diagnosis }\end{array}$} & \multirow[t]{2}{*}{$\begin{array}{l}\text { Secondary } \\
\text { diagnosis }\end{array}$} & \multirow{3}{*}{$\begin{array}{l}\text { Erosion/ } \\
\text { ulcer } \\
\\
5\end{array}$} & \multirow{3}{*}{$\begin{array}{l}\text { Depth } \\
\text { (\%) of the } \\
\text { lesion } \\
\quad 6\end{array}$} & \multirow{3}{*}{$\begin{array}{l}\text { Size }(\mathrm{mm}) \text { : } \\
\text { length } \times \\
\text { width } \\
\\
7\end{array}$} & \multirow{3}{*}{$\begin{array}{r}\text { Technique } \\
\\
8\end{array}$} & \multirow{3}{*}{$\begin{array}{c}\text { Healing } \\
\text { time } \\
\text { (in days) } \\
\\
9\end{array}$} & \multirow{3}{*}{$\begin{array}{c}\text { Success } \\
(\text { yes/no })\end{array}$} & \multirow{3}{*}{$\begin{array}{c}\text { Follow-up } \\
\text { (in months) } \\
11\end{array}$} & \multicolumn{2}{|c|}{ Recurrence } & \multirow[t]{2}{*}{ Comments } & \multirow{3}{*}{$\begin{array}{c}\text { Total } \\
\text { number of } \\
\text { AMT } \\
\text { treatments } \\
15\end{array}$} \\
\hline & & & & & & & & & & & $(Y e s / N o)$ & $\begin{array}{c}\text { Time } \\
\text { (in weeks) }\end{array}$ & & \\
\hline & & & 4 & & & & & & & & 12 & 13 & 14 & \\
\hline 19/M & 1 & $\begin{array}{l}\text { Neurotrophic } \\
\text { keratitis }\end{array}$ & Corneal scar & Ulcer & 60 & $1.5 \times 2.4$ & $S=1 P+2 G$ & 97 & $\mathrm{~N}$ & 12 & $\mathrm{~N}$ & - & Facial paralysis & 1 \\
\hline $76 / \mathrm{M}$ & 2 & $\begin{array}{l}\text { Pseudophakic } \\
\text { bullous } \\
\text { keratopathy }\end{array}$ & - & Ulcer & 60 & $1.1 \times 1.5$ & $\mathrm{~S}=1 \mathrm{P}+1 \mathrm{G}$ & 28 & Y & 15 & $\mathrm{~N}$ & - & $\begin{array}{l}\text { High myopia, } \\
\text { Recurrence treated } \\
\text { and resolved by } \\
\text { medical therapy }\end{array}$ & 1 \\
\hline $28 / F$ & 2 & $\begin{array}{l}\text { Corneal } \\
\text { amyloidosis }\end{array}$ & - & Erosion & 10 & $4.5 \times 2.5$ & $1 \mathrm{G}$ & 30 & Y & 8 & Y & 28 & $\begin{array}{l}\text { Recurrence treated } \\
\text { and resolved by } \\
\text { medical therapy }\end{array}$ & 1 \\
\hline $44 / \mathrm{M}$ & 2 & Alkali burn & Failed graft & Erosion & 10 & $3.0 \times 1.5$ & $1 \mathrm{P}$ & 2 & Y & 1 & $\mathrm{~N}$ & - & - & 1 \\
\hline $80 / \mathrm{F}$ & 3 & $\begin{array}{l}\text { Pseudopem- } \\
\text { phigoid }\end{array}$ & $\begin{array}{l}\text { Pseudo- } \\
\text { phakic } \\
\text { bullous } \\
\text { keratopathy }\end{array}$ & Ulcer & 50 & $9.0 \times 7.0$ & $S=1 P+2 G$ & 70 & $\mathrm{~N}$ & 12 & $\mathrm{~N}$ & - & - & 1 \\
\hline $45 / F$ & 1 & Alkali burn & - & Ulcer & 50 & $7.0 \times 7.0$ & $\mathrm{~S}=1 \mathrm{P}+1 \mathrm{G}$ & 29 & Y & 16 & Y & 52 & $\begin{array}{l}\text { Recurrence treated } \\
\text { and resolved by } \\
\text { medical therapy }\end{array}$ & 1 \\
\hline $41 / \mathrm{M}$ & 2 & $\begin{array}{l}\text { Melting metal } \\
\text { burn }\end{array}$ & $\begin{array}{l}\text { Cicatrical } \\
\text { entropion }\end{array}$ & Erosion & 10 & $2.8 \times 1.4$ & $1 G$ & 18 & Y & 39 & Y & 52 & $\begin{array}{l}\text { Ulcer and } \\
\text { descemetocele after } \\
\text { one year; recurrence } \\
\text { treated with } \\
\text { ASE + AMT(S) }\end{array}$ & 2 \\
\hline $83 / F$ & 1 & $\begin{array}{l}\text { Herpetic } \\
\text { keratitis } \\
\text { (metaherpetic) }\end{array}$ & $\begin{array}{l}\text { Sympathetic } \\
\text { ophthalmia }\end{array}$ & Ulcer & 60 & $1.9 \times 1.6$ & $\mathrm{~S}=1 \mathrm{P}+1 \mathrm{G}$ & 12 & Y & 6 & $\mathrm{~N}$ & - & steroids + antivirals & 1 \\
\hline $78 / \mathrm{F}$ & 1 & $\begin{array}{l}\text { Herpetic } \\
\text { keratitis } \\
\text { (active } \\
\text { necrotizing) }\end{array}$ & $\begin{array}{l}\text { Bacterial } \\
\text { corneal ulcer }\end{array}$ & Ulcer & 30 & $2.0 \times 3.0$ & $\mathrm{~S}=1 \mathrm{P}+1 \mathrm{G}$ & 17 & Y & 6 & Y & 26 & $\begin{array}{l}\text { New ulcer after } 6 \\
\text { months; good } \\
\text { response after } \\
\text { conjunctival flap, } \\
\text { steroids + antivirals }\end{array}$ & 1 \\
\hline $48 / \mathrm{M}$ & 1 & $\begin{array}{l}\text { Ocular } \\
\text { trauma }\end{array}$ & $\begin{array}{l}\text { Failed } \\
\text { graft }\end{array}$ & Ulcer & 40 & $6.0 \times 4.0$ & $1 \mathrm{P}$ & 45 & $\mathrm{~N}$ & 12 & $\mathrm{Y}$ & 23 & $\begin{array}{l}\text { New ulcer after } 5.4 \\
\text { months, second } \\
\text { AMT }\end{array}$ & 2 \\
\hline $51 / \mathrm{M}$ & 2 & $\begin{array}{l}\text { Herpetic } \\
\text { keratitis (active } \\
\text { necrotizing) }\end{array}$ & - & Ulcer & 60 & $6.0 \times 5.0$ & $S=1 P+2 G$ & 20 & Y & 26 & Y & 7 & $\begin{array}{l}\text { Developed } \\
\text { calcification, } \\
\text { treated by PK, } \\
\text { steroids + antivirals }\end{array}$ & 3 \\
\hline $64 / \mathrm{F}$ & 2 & $\begin{array}{l}\text { Herpetic } \\
\text { keratitis } \\
\text { (metaherpetic) }\end{array}$ & - & Erosion & 10 & $2.0 \times 2.0$ & $S=1 P+1 G$ & 22 & Y & 6 & Y & 12 & $\begin{array}{l}\text { Recurrence treated } \\
\text { and resolved by }\end{array}$ & 1 \\
\hline
\end{tabular}


Table 1 (Continued)

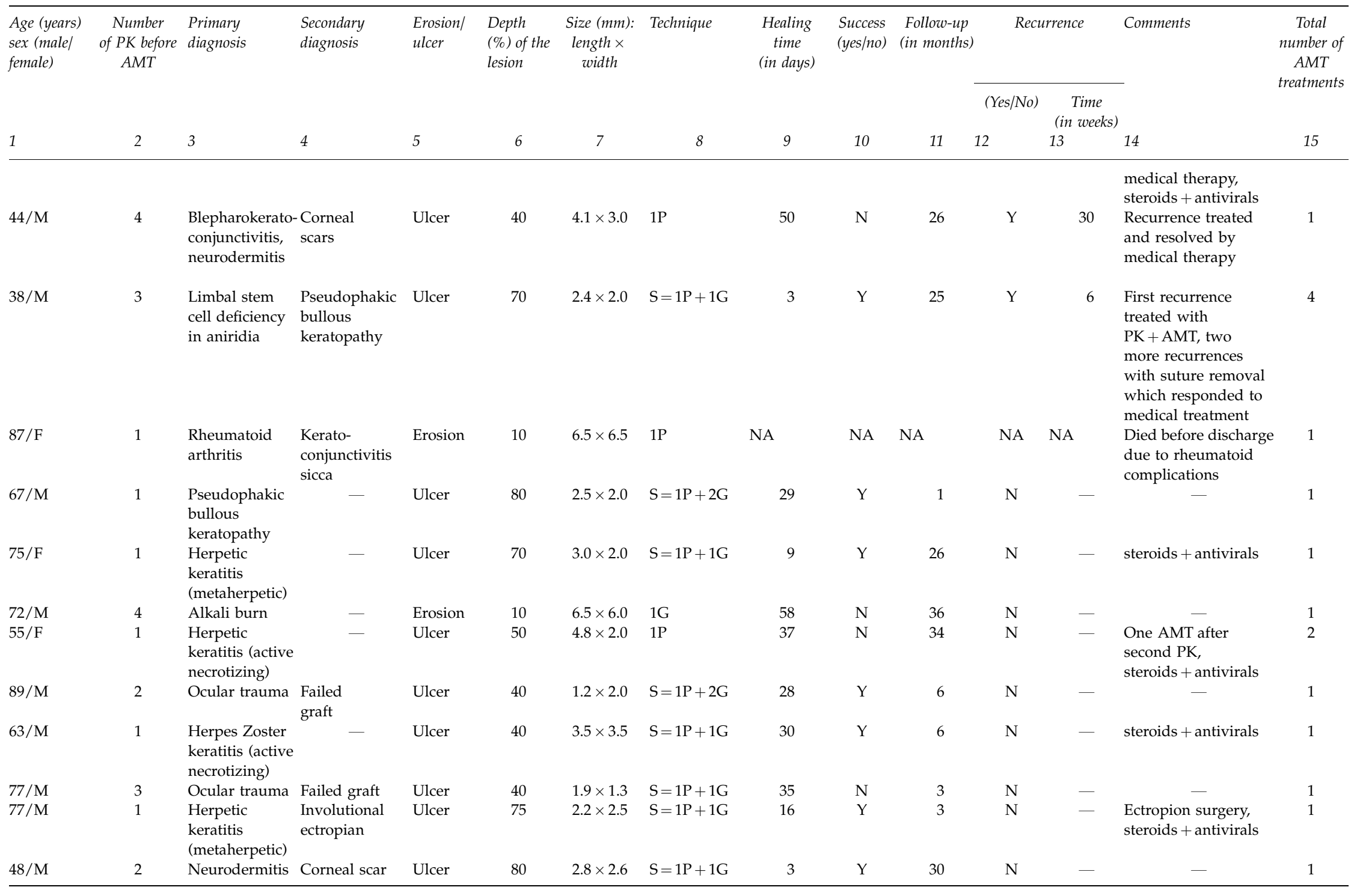


Table 2 Primary success and recurrence rate of amniotic membrane transplantation for the treatment of persistent corneal epithelial defect in eyes after penetrating keratoplasty

\begin{tabular}{|c|c|c|c|c|c|c|c|c|c|}
\hline \multirow[t]{2}{*}{ Location of the defect } & \multicolumn{3}{|c|}{ Total defects } & \multicolumn{3}{|c|}{ Surgical success } & \multicolumn{3}{|c|}{ Recurrence } \\
\hline & Erosion & Ulcer & Total & Erosion & Ulcer & Total & Erosion & Ulcer & Total \\
\hline Central & 2 & 3 & 5 & 2 & 3 & 5 & 2 & 1 & 3 \\
\hline Central-midperipheral & $2+1^{\mathrm{a}}$ & 6 & $8+1^{\mathrm{a}}$ & 1 & 5 & 6 & 1 & 2 & 3 \\
\hline Midperipheral & 1 & 4 & 5 & 1 & 2 & 3 & - & 1 & 1 \\
\hline Midperipheral-peripheral & - & 3 & 3 & - & 2 & 2 & - & - & - \\
\hline Peripheral & - & - & - & - & - & - & - & - & - \\
\hline Central-midperipheral-peripheral & - & 2 & 2 & - & - & - & - & - & - \\
\hline Total & $5+1^{\mathrm{a}}$ & 18 & $23+1^{a}$ & 4 & 12 & 16 & 3 & 4 & 7 \\
\hline
\end{tabular}

The cornea was divided into three areas by three imaginary concentric circles referring to the geographic centre of the cornea. According to the location, lesions were classified into three major groups. The first circle with $4 \mathrm{~mm}$ diameter indicated the location of central lesions, the second circle with $8 \mathrm{~mm}$ diameter marked the midperipheral lesions (both within the graft margin), and the most peripheral circle with $12 \mathrm{~mm}$ diameter limited lesions on the peripheral cornea.

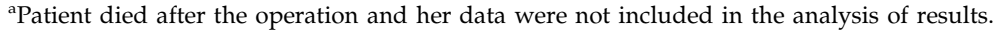

Two additional recurrences occurred in two eyes with ulcers but without 'surgical success'.

defects with endothelial decompensation or infiltration of the entire cornea.

In our study, all three techniques were implemented including three graft (12\%), five patch $(21 \%)$, and the largest group consisting of sixteen sandwich $(67 \%)$ with two $(n=11)$ or three $(n=5)$ AM layers. A therapeutic contact lens was applied in all cases except in patient 8 , who had conjunctival fornix shortening due to previous severe ocular burn with melting aluminium. The sutures and contact lens were usually removed after the first month.

Postoperative care consisted of preservative-free antibiotics (Ofloxacin 0.3\%) three times a day, artificial tears 10 times a day, and preservative-free cycloplegics two times a day. All patients received intraoperative injection of $150 \mathrm{mg}$ Decortin quickly to be tapered over a 1- or 2-week period. Topical treatment with corticosteroids was restricted to two or three drops of prednisolone-acetate as long as the contact lens was in place. All patients with herpetic eye disease were treated with $5 \times 400 \mathrm{mg}$ of systemic Acyclovir for 4 weeks and then with $2 \times 400 \mathrm{mg}$ Acyclovir for at least 6 months. Topically, those patients received trifluorthymidine drops four times a day.

\section{Main outcome measures}

Main outcome measures included surgical success, if the epithelium was closed within 4 weeks after AMT, and 'recurrence', if a new epithelial defect developed during the follow-up after complete closure of the epithelium. Through the study period, one patient with a long-term history of rheumatoid arthritis died; her data were not included in the analysis of the results.

\section{Results}

\section{Surgical success}

One month after the AMT, 16 eyes (70\%) had achieved complete epithelialization (ie, surgical success). Four out of five eyes with erosions achieved surgical success (80\%). In these cases, the defects were limited to either central and/or midperipheral locations of the graft. The only eye with primary failure had the lesion on both the central and midperipheral cornea. Twelve out of eighteen eyes with ulcers achieved surgical success (67\%). From the 12 successful eyes, the defects were located on the graft in 10 eyes (93\%) and the remaining two eyes (7\%) had the defect involving the graft-host junction (see Table 2).

Rate of surgical success was correlated inversely with the number of previous PKs before AMT. Out of 16 successful cases, surgical success rate was $83 \%$ (in 15 out of 18 eyes) for the group of eyes with two or less previous PKs, and the rate was only 20\% (in one out of five eyes) for the group of eyes with three or more previous PKs. All the eyes $(n=4)$ with erosions, which had surgical success, had two previous PKs whereas, the only unsuccessful eye had more than three PKs. Eyes with ulcers, which had surgical success $(n=12)$, had two or less previous PKs in 11 eyes and three or more PKs in only one eye.

Rate of surgical success was highest $(81 \%)$ when sandwich technique was used, whereas it was $67 \%$ or $25 \%$ when graft or patch techniques were used, respectively (Figure 2). Rate of surgical success was highest $(86 \%)$ in cases with herpetic keratitis (Table 3 ). In terms of visual acuity, no significant difference was found between preoperative and postoperative values. 


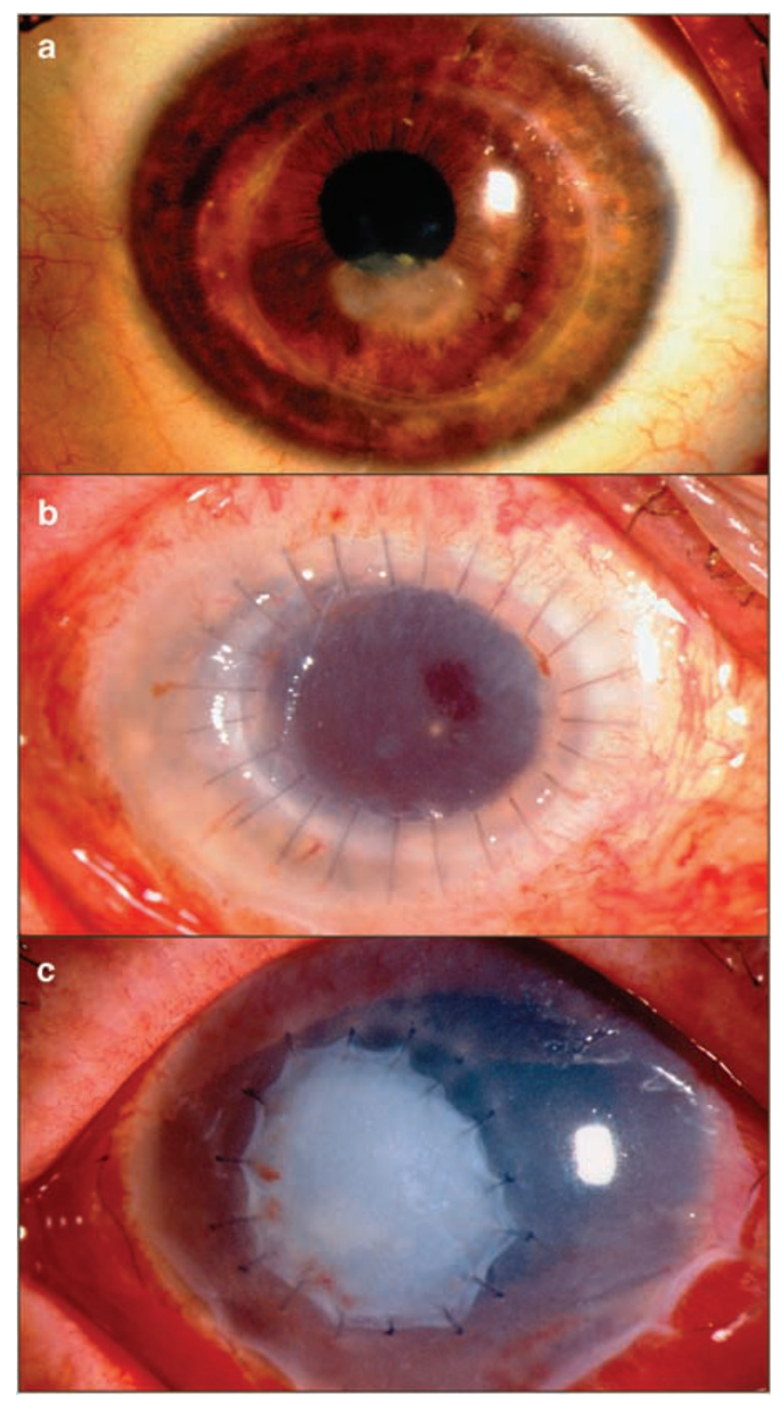

Figure 1 (a) Paracentral AM 'graft' in Goldenhar syndrome; (b) AM 'patch' for shallow PED after eccentric elliptical excimer laser keratoplasty à chaud for perforated herpetic ulcer; (c) AM 'triple graft sandwich' for persistent deep corneal ulcer due to pseudomonas aeruginosa.

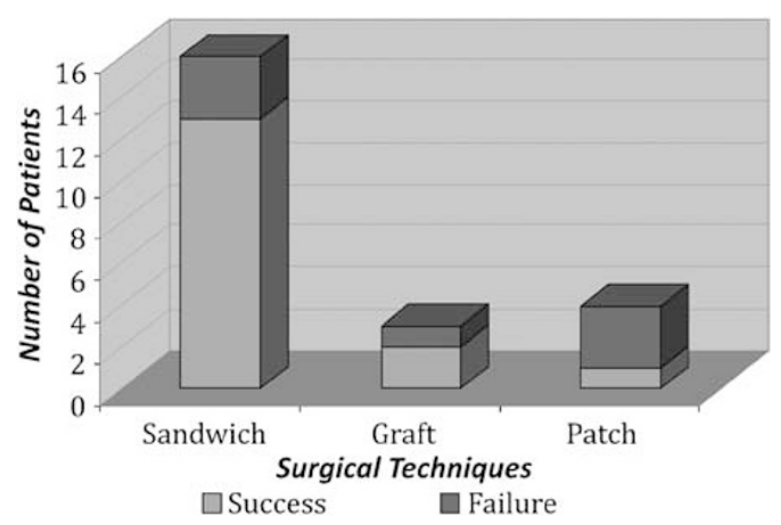

Figure 2 Graph showing surgical success and failure with three different surgical techniques.

\section{Recurrence}

From the 16 successful eyes, seven eyes (44\%) had at least one 'recurrence' during a mean follow-up of $16 \pm 13$ (range: 6-39) months. Fifty-seven percent (57\%) of recurrences after surgical success was present before 26 (range: 6-52) weeks. In cases with erosions, recurrence was observed in three out of four successful eyes (75\%) after 12, 28, and 52 weeks during a mean follow-up of 18 (range: 6-39) months. Similarly, during a mean follow-up of 18 (range: 6-26) months, four out of twelve successful eyes with ulcers (33\%) had recurrence after 7, 26, 30, and 52 weeks. The mean follow-up in nine eyes $(56 \%)$ without any recurrence was $10 \pm 11$ (range: $3-30$ ) months.

The surgical techniques used were compared among eyes with or without recurrence. Eyes, which had surgical success without any recurrence, had one patch and eight sandwich with two $(n=6)$ and three $(n=2)$ AM layers. Eyes, which had recurrence after the initial success had two graft and five sandwich with two $(n=4)$ and three $(n=1)$ AM layers. Recurrence was found only in 38\% of eyes treated with the sandwich technique, whereas it was 90 and $100 \%$ in eyes treated with graft or patch only. Rate of recurrence was lowest $(25 \%)$ in cases with pseudophakic bullous keratopathy (Table 3).

The correlation between recurrence and the time interval between AMT and previous PK, revealed an interesting finding. There was no recurrence after AMT in eyes where the time interval was short (1-7 months) or very long (79-120 months). In all eyes with recurrence, the AMT was performed between 10 and 43 months after PK.

\section{Discussion}

In eyes with PEDs refractory to medical therapy, several options may be considered including AMT. Our study suggests that AMT may be considered for treating erosions and ulcers in eyes with a previous history of PK. However, a high-recurrence rate may follow after the initial surgical success. Recently, we introduced simultaneous AMT in high-risk keratoplasty eyes with impending epithelial healing problems. ${ }^{20}$ Besides the rapid and stable re-epithelialization, simultaneous AMT seems to have immunological advantages without longterm impairment of optical quality of the corneal graft. In addition, AM may decrease alloimmunogenity of cotransplanted corneas. ${ }^{21}$

In this study, the common denominator in all of our patients is the condition caused by one or more previous PKs with damage to corneal sensory nerves. The central area of corneal graft never recovers normal sensitivity, which may have significant implication on the epithelial cell integrity of corneal grafts. ${ }^{22}$ Postkeratoplasty donor 
Table 3 Primary success and recurrence rates of amniotic membrane transplantation after penetrating keratoplasty for various etiologies

\begin{tabular}{|c|c|c|c|c|}
\hline $\begin{array}{l}S l \\
n o .\end{array}$ & Etiology & $\begin{array}{l}\text { Number of } \\
\text { eyes }\end{array}$ & $\begin{array}{l}\text { Success rate } \\
\text { (\%) }\end{array}$ & $\begin{array}{l}\text { Recurrence rate } \\
\text { (\%) }\end{array}$ \\
\hline (1) & Herpetic keratitis & 8 & $7(86)$ & $3(38)$ \\
\hline (5) & Pseudophakic bullous keratopathy & 4 & $3(75)$ & $1(25)$ \\
\hline (2) & Alkali burn & 3 & $2(67)$ & $1(33)$ \\
\hline (3) & Ocular trauma & 3 & $1(33)$ & $1(33)$ \\
\hline (4) & Neurodermitis & 2 & $1(50)$ & $1(50)$ \\
\hline (6) & $\begin{array}{l}\text { Others (Corneal amyloidosis, rheumatoid arthritis, melting metal burn, and neurotrophic } \\
\text { keratitis) }\end{array}$ & 4 & $2(50)$ & $2(50)$ \\
\hline
\end{tabular}

corneal epithelium is thought to be vulnerable to insult because of denervation, replacement with host derived corneal epithelium, and exposure to various topical medication. ${ }^{4}$ In addition to the general risks after PK, our patients had additional risk factors due to the primary pathologies, such as herpetic infection (simplex or zoster), alkali burn, thermal burn, aniridia, and ocular trauma, which go along with damage of the corneal nerves and/or the LSCs. ${ }^{23}$

Although it is not proven histologically, clinical findings, ${ }^{24}$ such as vascularization, conjunctivalization, and chronic keratitis are suggestive of LSC deficiency (LSCD) in our patients. Risk factors, such as keratoconjunctivitis sicca, pseudopemphigoid, cicatricial entropion, involutional ectropion, and facial nerve palsy, which can delay closure of the epithelial defect, are also found in these patients. Primary or additional therapeutic options include pressure patch, temporal or permanent tarsorrhaphy, and other types of lid surgery as appropriate. $^{25}$

In our study, in spite of the aforementioned risk factors, the surgical success rate was $70 \%$, which is comparable to earlier studies. ${ }^{18,26-29}$ Our study results suggest that surgical success is inversely proportional to the number of previous PKs. It was found to be four times better in patients with two or less previous PKs compared to those with three or more previous PKs. The following reasons may be attributed to the $30 \%$ primary failure rate in our patients. Increased number of surgeries might have produced a neurotrophic state, which led to the failure of AMT. The neurotrophic state usually has deleterious effects on the corneal epithelium. ${ }^{30}$ In addition, multiple PKs might have further diminished ocular sensitivity and decreased LSC population. ${ }^{18}$ Although PK does not cause specific trauma to LSCs, increased demand on the host epithelium to repopulate the donor graft is probably a factor for the development of LSCD or exhaustion. In addition, recurrent inflammation, especially in herpes simplex keratits, and also disturbances of the tear-film distribution must be considered risk factors for the failure after AMT.
In terms of visual acuity, no significant difference was found between preoperative and postoperative values. This is a retrospective study comprising cases with poor prognosis and risk factors due to the primary pathologies including bullous keratopathy due to irreversible graft failure, and/or widespread infectious stromal infiltration with resulting major scarring after healing thus significantly limiting the potential improvement of visual acuity. Moreover, integration pattern of AM after applying the graft technique result in major visual limitation, if located in the pupillary region. ${ }^{31}$

In this study, it was found that defects limited only to the centre of the graft had a better surgical success rate. This might be due to the size of the lesions. Surgical success rate was highest using the sandwich technique, which is a combination of 'inlay or graft' and 'overlay or patch' techniques, and hence, conveys advantages of both the procedures. ${ }^{32}$ However, this is a retrospective, non-randomized study and no specific protocol was followed for the choice of surgical technique. Hence, it is difficult to truly compare the results between the techniques applied. In addition to the graft serving as a new BM, the patch prevents exposure and dryness and promotes healing in eyes with poor blink reflex. Furthermore, the AM matrix provides growth factors to speed up epithelial proliferation. Indeed, it has been demonstrated that multilayer applications heal better than single layer. ${ }^{27,28}$ This study further revealed that patients treated with the sandwich technique had less recurrences compared to the other two techniques. At this time, it is unclear how the time interval between PK and AMT influences the incidence of recurrences.

The variety of diseases did not differ significantly for both surgical success and primary failure groups, although the severity of diseases was greater in the failure group. Primary failure might be due to more pronounced loss of LSCs. In agreement with a study by Espana $^{33}$ et al, we found that patients with bullous keratopathy had the highest success rate and the lowest recurrence rate. 
The recurrence rate was higher $(44 \%)$ in our study as compared to previous studies. ${ }^{15,18,29}$ This may be due to multiple risk factors in the presented eyes after PK. Although AMT can treat the current pathology, primary neurotrophic components will still persist since adequate LSCs and intact sensory innervation is mandatory for repairing and maintaining ocular surface integrity.

Hence, recurrence is to be expected after termination of the biological effects of AM. Besides long-term systemic acyclovir and initial high-dose steroid treatment, eyes with herpetic keratitis might need additional treatment, such as hyaluronic acid drops and autologous serum drops to avoid recurrences. ${ }^{34}$ One eye with herpetic keratitis developed clinically significant calcification of the cornea, which has been attributed to the topical use of phosphate-containing eye drops. ${ }^{35}$

In conclusion, AMT may be beneficial in the treatment of PEDs after PK. Especially when applying the sandwich technique, the primary success rate was comparable to that in PED without previous PK. In contrast, recurrences seem to be more frequent, if PK preceded AMT. Treatment of systemic or other associated ocular diseases is indispensable to prevent primary failure or recurrence.

\section{References}

1 Pfister RR. The biology of persistent epithelial defects. In: Brightbill FS (ed). Corneal Surgery: Theory, Techniques and Tissue. Mosby: St Louis, 1999, pp 18-27.

2 Tsai RJF, Tseng SCG. Effect of stromal inflammation on the outcome of limbal transplantation for corneal surface reconstruction. Cornea 1995; 14: 439-449.

3 Seitz B, Langenbucher A, Nguyen NX, Römer AK, Küchle M, Naumann GOH. Risk factors for new corneal epithelial defects after penetrating keratoplasty. 2003 AAO-poster, Abstract; 168.

4 Nelson JD. Epithelial problems. In: Brightbill FS (ed). Corneal Surgery: Theory, Techniques and Tissue. Mosby: St Louis, 1999, pp 18-27.

5 Doughman DJ. Prolonged donor cornea preservation in organ culture: long-term clinical evaluation. Trans Am Ophthalmol Soc 1980; 78: 567-628.

6 Sonnenberg A, Calafat J, Janssen H, Daams H, van der Raaij-Helmer LM, Falcioni R et al. Integrin alpha 6/beta 4 complex is located in hemidesmosomes, suggesting a major role in epidermal cell-basement membrane adhesion. J Cell Biol 1991; 113: 907-917.

7 Khodadoust AA, Silverstein AM, Kenyon DR, Dowling JE. Adhesion of regenerating corneal epithelium: the role of basement membrane. Am J Ophthalmol 1968; 65: 339-348.

8 Barcellos-Hoff MH, Aggeler J, Ram TG, Bissell MJ. Functional differentiation and alveolar morphogenesis of primary mammary cultures on reconstituted basement membrane. Development 1989; 105: 223-225.

9 Guo M, Grinnell F. Basement membrane and human epidermal differentiation in vitro. J Invest Dermatol 1989; 93: $372-378$.
10 Streuli CH, Bailey N, Bissell MJ. Control of mammary epithelial differentiation: basement membrane induces tissue-specific gene expression in the absence of cell-cell interaction and morphological polarity. J Cell Biol 1991; 115: 1383-1395.

11 Meller D, Tseng SC. Conjunctival epithelial cell differentiation on amniotic membrane. Invest Ophthalmol Vis Sci 1999; 40: 878-886.

12 Boudreau N, Sympson CJ, Werb Z, Bissell MJ. Suppression of ICE and apoptosis in mammary epithelial cells by extracellular matrix. Science 1995; 267: 891-893.

13 Boudreau N, Werb Z, Bissell MJ. Suppression of apoptosis by basement membrane requires three-dimensional tissue organization and withdrawal from the cell cycle. Proc Natl Acad Sci USA 1996; 93: 3509-3513.

14 Heiligenhaus A, Bauer D, Meller D, Steuhl KP, Tseng SC. Improvement of HSV-1 necrotizing keratitis with amniotic membrane transplantation. Invest Ophthalmol Vis Sci 2001; 42: 1969-1974.

15 Letko E, Stechschulte SU, Kenyon KR, Sadeq N, Romero TR, Samson CM et al. Amniotic membrane inlay and overlay grafting for corneal epithelial defects and stromal ulcers. Arch Ophthalmol 2001; 119: 659-663.

16 Azuara-Blanco A, Pillai CT, Dua HS. Amniotic membrane transplantation for ocular surface reconstruction. $\mathrm{Br} \mathrm{J}$ Ophthalmol 1999; 83: 399-402.

17 Dua HS, Azuara-Blanco A. Amniotic membrane transplantation. Br J Ophthalmol 1999; 83: 748-752.

18 Lee SH, Tseng SC. Amniotic membrane transplantation for persistent epithelial defects with ulceration. Am J Ophthalmol 1997; 123: 303-312.

19 Seitz B, Ferreira de Souza R, Hoffmann-Rummelt C, Hofmann-Rummelt C, Sauer R, Kruse FE et al. Histopathology and ultrastructure of human corneas after amniotic membrane transplantation. Arch Ophthalmol 2006; 124: 1487-1490.

20 Seitz B, Sauer R, Wenkel H, Langenbucher A, Naumann GOH. Simultaneous amniotic membrane transplantation in high-risk keratoplasty. Ophthalmologe 2003; 100(Suppl.1): S29.

21 Kubo M, Sonoda Y, Muramatsu R, Usui M. Immunogenicity of human amniotic membrane in experimental xenotransplantation. Invest Ophthalmol Vis Sci 2001; 42 1539-1546.

22 Rao GN, John T, Ishida N, Aquavella JV. Recovery of corneal sensitivity in grafts following penetrating keratoplasty. Ophthalmology 1985; 92: 1408-1411.

23 Schwartz GS, Holland EJ. Iatrogenic limbal stem cell deficiency. Cornea 1998; 7: 31-37.

24 Puangsricharern V, Tseng SCG. Cytologic evidence of corneal diseases with limbal stem cell deficiency. Ophthalmology 1995; 102: 1476-1485.

25 Pfister RR. Clinical measures to promote corneal epithelial healing. Acta Ophthalmologica 1992; 70(Suppl.): 73-83.

26 Hanada K, Shimazaki J, Shimmura S, Tsubota K. Multilayered amniotic membrane transplantation for severe ulceration of the cornea and sclera. Am J Ophthalmol 2001; 131: 324-331.

27 Kruse FE, Rohrschneider K, Völcker HE. Multilayer amniotic membrane transplantation for reconstruction of deep corneal ulcers. Ophthalmology 1999; 106: 1504-1511.

28 Prabhasawat P, Tesavibul N, Komolsuradej W. Single and multilayer amniotic membrane transplantation for persistent corneal epithelial defect with or without stromal 
thinning and perforation. $\mathrm{Br}$ J Ophthalmol 2001; 85: 1455-1463.

29 Ferreira de Souza R, Hofmann-Rummelt C, Kruse FE, Seitz B. Multilayer amniotic membrane transplantation for corneal ulcers not treatable by conventional therapy - a prospective study of the status of cornea and graft during follow-up. Klin Monatsbl Augenheilkd 2001; 218: 528-534.

30 Beuerman RW, Schimmelpfennig B. Sensory denervation of the rabbit cornea affects epithelial properties. Exp Neurol 1980; 69: 196-201.

31 Resch MD, Schlötzer-Schrehardt U, Hofmann-Rummelt C, Sauer R, Kruse FE, Beckmann MW, Seitz B. Integration patterns of cryopreserved amniotic membranes into the human cornea. Ophthalmology 2006; 113: 1927-1935.
32 Seitz B, Ferreira de Souza R, Hoffmann-Rummelt C, Langenbucher A, Naumamnn GOH. Graft, Patch or Sandwich for persistent corneal ulcers - differential techniques of amniotic membrane transplantation. Clin Exp Ophthalmol 2002; 30(Suppl.): A122.

33 Espana EM, Grueterich M, Sandoval H, Solomon A, Alfonso E, Karp CL et al. Amniotic membrane transplantation in eyes with poor visual potential. J Cataract Refract Surg 2003; 29: 279-284.

34 Ferreira de Souza R, Kruse FE, Seitz B. Autologous serum for otherwise therapy resistant corneal epithelial defects - prospective study on the first 70 eyes. Klin Monatsbl Augenheilkd 2001; 218: 720-726.

35 Anderson SB, Ferreira de Souza R, Hofmann-Rummelt C, Seitz B. Corneal calcification after amniotic membrane transplantation. Br J Ophthalmol 2003; 87: 587-591. 